University of Warwick institutional repository: http://go.warwick.ac.uk/wrap This paper is made available online in accordance with publisher policies. Please scroll down to view the document itself. Please refer to the repository record for this item and our policy information available from the repository home page for further information.

To see the final version of this paper please visit the publisher's website. Access to the published version may require a subscription.

Author(s): Brooks V.

Article Title: Role of External Examinations in the Making of Secondary Modern Schools in England 1945-65'

Year of publication: 2008

Link to published version: http://dx.doi.org/10.1080/00467600600909892

Publisher statement: None 


\section{The Role of External Examinations in the Making of Secondary Modern Schools in England 1945-1965}

Val Brooks

\section{Introduction}

... the examination system is no friend to whom one can trust in blind confidence: from its first guise as a servant it may at any moment reveal itself as a hard and unsympathetic master: and it is far the most dangerous of the mechanical instruments which are employed in the service of education. ${ }^{1}$

Prior to the Second World War, just short of ten per cent of the population received a secondary education whilst the majority completed their education in elementary schools where the leaving age was fourteen. Although the 1944 Education Act made a free secondary education available to all up to the age of fifteen, it 'recommended no particular form of secondary provision'. ${ }^{2}$ However, 'the Norwood Report of 1943 favoured tripartism', ${ }^{3}$ a system based on the theory of three broad categories of children, with different types of minds, each requiring a particular type of education tailored to their aptitudes and intellectual

\footnotetext{
${ }^{1}$ Norwood, C. The English Tradition of Education. London: John Murray, 1929: 208-209.

${ }^{2}$ Lawn, M. and Ozga, J. "Unequal Partners: Teachers under Indirect Rule." British Journal of Sociology of Education 7, no. 2 (1986): 225-238.

${ }^{3}$ Ibid.
} 
capacities. Grammar schools would educate a minority of intellectually able pupils while technical schools would cater for those who displayed a technical or vocational bias. Those remaining, approximately three-quarters of the eleven-to-fifteen age range, would be educated in a new type of school - the secondary modern - which would provide: "'a balanced training of mind and body and a correlated approach to humanities, Natural Science and the arts", not with any specific job or occupation in view but in order to "make a direct appeal to interests, which it would awaken by practical touch with affairs"'. 4 Thus, secondary modern schools (SMSs) were to be the protagonists in 'a great adventure', part of 'the boldest investment ... that any war-crippled nation has ever made - an investment in the children, the citizens of the future'. ${ }^{5}$

In the event, only a handful of secondary technical schools was created, ${ }^{6}$ making the state system essentially bipartite in character, excepting some early experiments with comprehensive schooling. A selection test, taken in the final year of primary schooling, was the principal means by which children were allocated to schools. The eleven-plus selected those deemed suited to a grammar school education, while the majority went elsewhere - usually the local SMS. Despite the 'political fever' ${ }^{7}$ surrounding its inception, the SMS quickly became the Cinderella of the secondary system, inadequately funded

\footnotetext{
${ }^{4}$ McCulloch, G. Failing the Ordinary Child? The Theory and Practice of Working-class Secondary Education. Buckingham: Open University Press, 1998: 56.

${ }^{5}$ Ministry of Education. The New Secondary Education. Ministry of Education Pamphlet 9 London: HMSO, 1947: 3.

${ }^{6}$ McCulloch, Failing the Ordinary Child?, 60.

${ }^{7}$ Kneebone, R. M. T. I Work in a Secondary Modern School. London: Routledge and Kegan Paul, 1957: xiv.
} 
and overshadowed by its more prestigious counterpart, the grammar school, and the rise of comprehensive education. Likewise, much of the research into SMSs has been carried out almost by default, concerned not with these schools as significant in their own right, but as part of a wider quest to determine whether selective or non-selective systems offer more effective forms of education. Most of the research in which SMSs feature has been quantitative, ${ }^{8}$ reflecting an ongoing preoccupation with the attainments and attitudes of pupils educated in different types of schools. ${ }^{9}$ It is not simply that SMSs have rarely occupied centre stage. There has also been a tendency to consign them to the shadows, obscuring unpalatable questions that they raise. Thus, although the debate over the future of grammar schools continues to this day, the concomitant question, about the fate of SMSs, has received comparatively little attention. Although the stigmatising label, 'secondary modern', fell into disuse, with few schools choosing to describe themselves as such in recent years, the presence of grammar schools, even where they are isolated survivors of a bygone system rather than part of an LEA-wide approach, cannot but compromise the comprehensive ideal for neighbouring schools, making them more akin to the maligned SMSs than most would care to acknowledge.

\footnotetext{
${ }^{8}$ Notable exceptions which have examined SMSs as a social phenomenon include Taylor, $\mathrm{W}$. The Secondary Modern School. London: Faber and Faber, 1963; Hargreaves, D. Social Relations in a Secondary School. London: Routledge and Kegan Paul; McCulloch, Failing the Ordinary Child?; McCulloch, G. and Sobell, L. "Towards a Social History of the Secondary Modern Schools." History of Education 23, no. 3 (1994): 275-286; and Spencer, S. "Reflections on the 'site of struggle': Girls' Experience of Secondary Education in the late 1950s." History of Education 33, no. 4 (2004): 437-449.

${ }^{9}$ Recent examples from this extensive body of research include Atkinson, A. and Gregg, P. Selective Education: Who Benefits from Grammar Schools? Market and Public Organisation 11. Bristol: University of Bristol, Leverhulme Centre for Market and Public Organisation, 2004; Crook, D., Power, S. and Whitty, G. The Grammar School Question: a Review of Research on Comprehensive and Selective Education. London: University of London, Institute of Education, 1999; Schagen, I. and Schagen, S. "Analysis of National Value-added Datasets to Assess the Impact of Selection on Pupil Performance." British Educational Research Journal 29, no. 4 (2003): 561-582.
} 
The post-war system of secondary education raised fundamental questions about the justice of selective education on the one hand and its efficacy on the other - questions so complex and difficult to resolve that they are debated to this day. These questions have been given extensive treatment elsewhere ${ }^{10}$ and it is not the purpose of this paper to engage with them. Instead, it focuses on an aspect of SMSs which has received comparatively little attention: the role of external examinations - not as devices for measuring performance - but in shaping the character, ethos and fate of SMSs during their formative years. As McCulloch notes, there has been a 'tendency for assessment issues to be discussed in a technical language, detached from wider sociological, political, policy and ideological considerations' ${ }^{11}$ However, he argues that there is 'much potential' in the theme of assessment 'for exploration as a socio-political arena involving competing interests'. ${ }^{12}$ This paper contributes to that exploration by considering the agency of those teachers who - flying in the face of official policy designed to foreclose their use - entered SMS pupils for external examinations in ever-increasing numbers. The role played by external examinations in the 'making' of SMSs between 1945 and 1965 is explored, showing how examinations were used both by and 'against' these schools. The interplay between the schools and examinations is mutually enlightening, adding another dimension to the social history of SMSs and casting the social

\footnotetext{
${ }^{10}$ See footnote 9 .

${ }^{11}$ McCulloch, G. Educational Reconstruction: the 1944 Education Act and the Twenty-first Century. Ilford: Woburn Press, 1994: 134.

${ }^{12}$ Ibid., 134-35.
} 
significance of examinations in a light which may have been lost on a generation sated with testing.

As well as examining official documents from the period, this paper is concerned to capture the views and concerns of practising teachers. Gardner has argued that: 'The history of the teaching profession and its concerns - as opposed to the history of education itself - has, to date, been but poorly explored. It offers us a rich resource of collective experience which needs to be attended to more respectfully'. ${ }^{13}$ Letters, articles, books and opinion pieces written by serving teachers during the twenty-year period under consideration form a focus for attention. Like oral history, these written sources offer accounts whose depth and authenticity derives from their rootedness in the local, the personal and the particular. ${ }^{14}$ They afford vivid insights into contemporary opinion and experience yet the incidents which they describe are also 'culturally embedded', a 'microcosmic version of wider events'. ${ }^{15}$ Moreover, they shed fresh light on that class of teachers which emerged with the birth of SMSs generally less well-educated than their grammar schools counterparts ${ }^{16}$ and with lower social status. Examination successes were not only instrumental in SMSs' quest for parity of esteem with grammar schools; they also played a part in secondary modern teachers' bid for more equal status.

${ }^{13}$ Gardner, P. "The Early History of School-based Teacher Training." In Mentoring: Perspectives on School-based Teacher Education, edited by D. McIntyre, H. Hagger and M. Wilkin. London: Kogan Page, 1994: 22.

${ }^{14}$ Gardner. P. "Oral History in Education: Teacher's Memory and Teachers' History." History of Education 32, no. 2 (2003): 187.

${ }^{15}$ Spencer, "Reflections on the 'site of struggle"', 440-441.

${ }^{16}$ Davis noted that less than a fifth of modern school teachers were graduates whereas almost four-fifths of grammar school teachers enjoyed graduate status in Davis, J. A. M. "Examinations in Secondary Modern Schools - and who is to Control them." Forum 4, no. 2 (1962): 64. 


\section{A Hundred Years of External Examining 1850-1950}

... the problems of educational measurement are persistently perennial... the problems... that bothered our predecessors still bother us. ${ }^{17}$

For the purposes of this paper, the main interest of this period lies in the way it presages future events. In 1850, the English Journal of Education noted that: 'almost half a century ago examinations were nearly unknown in England'. ${ }^{18}$ In contrast, the period between 1850 and 1870 was characterised by the 'very sudden and sweeping victory won by the examination idea'.19 ${ }^{19}$ The earliest external examinations for secondary schools got underway in the $1850 s^{20}$ and were allowed to develop without central regulation until 1917. Free from state control, examinations sprang up on an ad hoc basis. Some were academic and general in nature ${ }^{21}$ but schools also used qualifying examinations established by the professions. ${ }^{22}$ When the Consultative Committee on Examinations in Secondary Schools reported in 1911, it described the prevailing situation as 'a

\footnotetext{
17 Ebel, R. L. Essentials of Educational Measurement. New Jersey: Prentice-Hall, 1972: 27.

${ }^{18}$ Quoted in Roach, J. Public Examinations in England 1850-1900. Cambridge: Cambridge University Press, 1971: 22.

19 Ibid., 4.

20 See Judges, A. V. "The Evolution of Examinations." In The World Year Book of Education 1969: Examinations, edited by J. A. Lauwerys and D. G. Scanlon. London: Evans, 1969; and Roach, Public Examinations in England.

${ }^{21}$ For instance, the Oxford Delegacy 'locals' (1858), Cambridge Syndicate 'locals' (1858) and examinations introduced by the University of London (1858).

22 These included examinations of the Royal Military Academy at Woolwich (1853), the Home Civil Service (1855) and the Indian Civil Service (1855).
} 
state of chaos' characterised by a range of examinations which was 'simply bewildering' ${ }^{23}$ Providing a general education that suited the needs of all whilst preparing pupils for the specific requirements of particular examining bodies had become a 'nightmare' for schools. ${ }^{24}$ This capacity for explosive growth in the absence of adequate provision of state-sponsored school-leaving qualifications would re-emerge in the 1950s.

Another recurring difficulty was the tendency of examinations to become 'high stakes', ${ }^{25}$ exerting a powerful backwash effect on what was taught, how it was taught and on pupils' approaches to learning. Thus, although the School Certificate (1917-1950) was intended to quell the backwash effect of examinations in schools, it quickly became established as a high stakes examination which dominated school life. Thus, the Spens Report found that: 'Most of our witnesses seemed unable to think of the curriculum except in terms of the examination, while some defined the curriculum entirely in such terms'. ${ }^{26}$ An extreme example of what this might mean was provided by Valentine: 'One of my students told me that in her own school the pupils studied the Hanoverian

\footnotetext{
${ }^{23}$ Board of Education. Examinations in Secondary Schools: Report of the Consultative Committee. Cmnd. 6004, London: HMSO, 1911: 1.

24 Board of Education. Secondary Education with Special Reference to Grammar Schools and Technical High Schools: Report of the Consultative Committee on Secondary Education. London: HMSO, 1939, (The Spens Report): 254.

${ }^{25}$ Stobart, G. and Gipps, C. Assessment: a Teacher's Guide to the Issues. London: Hodder and Stoughton, 1997 (third edition): 5-6.

${ }^{26}$ Board of Education, Secondary Education, 142.
} 
period of English history for four consecutive years... because that was to be the period selected for her School Certificate examination'. ${ }^{27}$

Another problem that has been 'persistently perennial' is the lack of social realism displayed by generations of policy makers who failed to acknowledge the necessary roles performed by external examinations at the microcosmic level - in individual schools and for particular pupils. For instance, the protestations of the 1931 Report on the School Certificate Examination convey indifference to the needs and interests of individual users:

... there is a common tendency to think of the examinations as if they existed for the benefit of individual pupils, anxious to secure exemption from this or that professional or University entrance examination, or for the benefit of yet other individuals, eager to obtain certificates and more especially 'Matriculation Certificates' as things valuable in themselves or possessing a special interest for employers. But this is to misconstrue the position. The examinations may serve these various ends, but it is not for these ends that they exist. ${ }^{28}$

Just over a decade later, the post-war policy on examinations would again set schools at odds with policy makers. One headteacher dismissed post-war

\footnotetext{
${ }^{27}$ Valentine, C. W. The Reliability of Examinations: an Enquiry. London: University of London Press, 1932: 16.

${ }^{28}$ The Schools Certificate Examination, being the Report of the Panel of Investigators appointed by the Secondary School Examinations Council to Enquire into the Eight Approved School Certificate Examinations held in the Summer of 1931. London: HMSO, 1932: 47.
} 
officials as 'starry-eyed faddists' ${ }^{29}$ whilst several regional surveys of teachers' views on the role of examinations in SMSs uncovered 'a considerable divergence of opinion between the Ministry of Education and the teachers' ${ }^{30}$

In fact, examinations conferred considerable benefits on schools during periods of expansion in secondary education. As early as 1868, a 'tonic' effect was evident:

While pointing out several serious faults, our Assistant Commissioners generally reported very highly of the good results which these examinations have already produced ... Mr Fitch ... remarks that all the best and most vigorous schools in his district made use of them, and that the good influence was perceptible, not only in the candidates sent in, but even in the lower classes ... strong proof ... of the good effect of thus constantly presenting a definite aim to the minds of teachers and scholars. $^{31}$

Nevertheless, by the 1940 s, observers were able to look back over a century much of which was characterised by the unbridled growth of external examinations and their increasingly powerful backwash effects on schools. Whilst some acknowledged the service which examinations had performed in

\footnotetext{
${ }^{29}$ McCarthy, E. F. in Letters to the Editor. Times Educational Supplement, $7^{\text {th }}$ October 1960 : 445.

${ }^{30}$ Taylor, Secondary Modern School, 188.

31 Schools Inquiry Commission. Report of the Schools Inquiry Commission. London: Eyre and Spottiswood for HMSO, 1868 (Taunton Report) Vol. 1: 330-331.
} 
the developing system of secondary education, ${ }^{32}$ examinations were vilified by others who were more powerfully struck by their pernicious effects on teaching, learning and the curriculum. As the Norwood Report opined '... the examination dictates the curriculum and cannot do otherwise; it confines experiment, limits free choice of subjects, hampers treatment of subjects, encourages wrong values in the classroom' ${ }^{33}$ It was this latter perspective which held sway in the creation of SMSs.

There was a spirit of idealism about what might be achieved if SMSs were unfettered by external examinations: 'We look forward to bold experiments and a wide variety of courses in the newer secondary schools ... Everything to do with children must have room to grow'. ${ }^{34}$ Great emphasis was placed on the freedom necessary for SMSs to develop a distinctive character. Pupils must be allowed to 'develop freely along their own lines' and teachers must be 'free to act'. ${ }^{35}$ Thus, SMSs were to be shielded from the stultifying effects of external examinations: ' $\ldots$ it is impracticable to combine a system of external examinations, which presupposes a measure of uniformity, with the fundamental conception of modern school education, which insists on variety'. ${ }^{36}$ SMSs were to develop instead a novel system of certification using records of achievement and internally conducted examinations. This 'would furnish a

\footnotetext{
${ }^{32}$ Board of Education, Examinations in Secondary Schools.

${ }^{33}$ Board of Education. Curriculum and Examinations in Secondary Schools: Report of the Committee of the Secondary School Examinations Council. London: HMSO, 1943, (The Norwood Report): 31.

${ }^{34}$ Ministry of Education, New Secondary Education, 4.

${ }^{35}$ Ibid., 30.

${ }^{36}$ Ibid., 46.
} 
certificate giving information of real importance ... and yet would preserve intact the freedom of the school'. ${ }^{37}$

A series of measures was introduced part of whose purpose was to exempt pupils in SMSs from external examinations in general and from the General Certificate of Education Ordinary Level (GCE O-Level), which would replace the School Certificate, in particular. Thus, although the school-leaving age was set at fifteen, the Schools' Grant Regulations provided financial support exclusively for GCE for which the minimum age of entry was sixteen; no other examination below sixteen was recognised, approved or financed by the state. As Broadfoot noted, these decisions had 'profound implications' for 'the educational system and the pupils within it ${ }^{38}$ - but nowhere more so than in SMSs, most of whose pupils left school at fifteen. Moreover, the O-Level pass level was fixed at the credit level of the School Certificate. Thus, a level originally intended to satisfy matriculation requirements for university entrants became the pass standard in a general school certificate intended to cater for the top twenty per cent of the ability range only.

Clearly, any SMS which attempted to ignore government policy and follow grammar schools down the external examining route would find a series of obstacles barring its way. In fact, an increasing number of schools chose to do

\footnotetext{
${ }^{37}$ Board of Education, Curriculum and Examinations in Secondary Schools, 32.

${ }^{38}$ Broadfoot, P. Assessment, Schools and Society. London: Methuen, 1979: 17.
} 
exactly that. One of the most astonishing features of this development was the momentum it gained in a short space of time. Although only a handful of candidates from non-grammar schools took the School Certificate prior to 1951, by 1954 over 5,500 candidates from 357 SMSs entered for O-Level. By 1956, O-Levels entries had risen again with over 8,500 candidates from about 600 SMSs. Two years later, this figure had almost doubled $(16,787$ entries) and it continued to rise sharply until the end of the decade. ${ }^{39}$ By 1960 , the number of children entering for O-Level was 39.4 per cent of the total number of SMS children aged fifteen in the previous January. ${ }^{40}$ This remarkable pace of development was also evident below GCE level where, in the absence of stateprovided qualifications, a number of awarding bodies such as the College of Preceptors, the Union of Educational Institutes and the Royal Society of Arts introduced school-leaving qualifications. Indeed, the number of individual entries for examinations of four of the largest non-GCE bodies increased by $70 \%$ between 1958 and 1959 whilst the number of centres rose by $45 \%$. $^{41}$ The full picture of external examining in SMSs during the 1950s also includes specialist examinations such as those conducted by the Pitman Examinations' Institute and the General Nursing Council and the local examining federations which sprang up in some areas. ${ }^{42}$ Nevertheless, an NUT survey which gauged the popularity of different fourth and fifth year ${ }^{43}$ examinations found that, even

\footnotetext{
39 Figures taken from Montgomery, R. J. Examinations: an Account of their Evolution as Administrative Devices in England. London: Longmans, 1965.

40 Taylor, Secondary Modern School, 118.

${ }^{41}$ Montgomery, Examinations: an Account, 15.

${ }^{42}$ For a description of one such federation, see Burdett, T. H. "Examinations in the Secondary Modern School." University of Nottingham Institute of Education Bulletin 33 (January 1960).

${ }^{43}$ Now described as Years 10 and 11.
} 
in SMSs, GCE topped the list. ${ }^{44}$ The situation was becoming as chaotic and bewildering as that found by the Consultative Committee in1911! Moreover, whilst external examinations proliferated, there was limited evidence of schools developing internal examinations. ${ }^{45}$

This is arguably one of the most spectacular examples of education policy failing to meet the realities of a situation. As Taylor observed: 'the schools have displayed a good deal more social realism than was characteristic of much postwar educational thought'. ${ }^{46}$ Even in official circles, it became increasingly difficult to overlook the fact that government policy was being widely ignored. Thus, only seven years after the implementation of these reforms, the Beloe Committee was appointed to re-consider the vexed question of secondary school examinations other than the GCE. ${ }^{47}$ In the following section, some of the reasons behind these events are explored.

\section{The Immediate Context: Post-War England and the Birth}

\section{of Secondary Modern Schools}

\footnotetext{
44 Morris, R. N. “The Cult of Examinations.” Education (6 May 1960): 1035.

45 Ministry of Education. Secondary School Examinations Other than the GCE: Report of a Committee Appointed by the Secondary School Examinations Council in July 1958. London: HMSO, 1960, (Beloe Report).

46 Taylor, W. "Changing Concepts of the Modern School - 1944 and 1959." Forum 2, no. 2 (Spring 1960): 63.

${ }^{47}$ Ministry of Education, Examinations Other than the GCE.
} 
Examination systems ... are deeply embedded in the social mores and assumptions of their countries. Those who want to maintain social elites and those who want to break their power, those who want to enhance the status of teachers and those who want to denigrate them, those who already control the selection of the best school leavers and those who want to place that control in different hands, will all be in contest as examining systems are up for renewal or reform. ${ }^{48}$

According to the President of the NUT, the task of introducing universal secondary education entailed taking a system which provided "'unequal opportunities in schools of unequal social standing, giving courses of unequal length and under unequal conditions" and replacing it with one which would provide "equal opportunities in schools of equal social standing giving courses of equal duration under equivalent conditions"'. ${ }^{49}$ Acknowledging these inequalities, the Ministry pledged that SMSs 'will have equally good buildings ... The maximum size of classes will be the same for all'. ${ }^{50}$ However, providing a free secondary education for all up to the age of fifteen entailed a tenfold increase in the size of the secondary cohort. It would have been a major commitment for a country enjoying economic prosperity but it was extremely ambitious for a country newly emerged from the throes of war. ${ }^{51}$

\footnotetext{
48 Black, P. Testing: Friend or Foe? The Theory and Practice of Assessment and Testing. London: Falmer, 1998: 144.

${ }^{49}$ Quoted in Lawn and Ozga, "Unequal Partners", 234.

${ }^{50}$ Ministry of Education, New Secondary Education, 7.

${ }^{51}$ Simon, B. Education and the Social Order 1940-1990. London: Lawrence and Wishart, 1991: 115-116.
} 
Almost immediately, the heady idealism surrounding the inception of SMSs came up against the harsh social realities of the situation in which these schools found themselves. Although some new schools were built to accommodate the expanded secondary cohort, many SMSs inherited the outdated buildings and facilities of the old elementary schools, and their staffs. The cramped and debilitating conditions this sometimes gave rise to are captured in the following descriptions of converted elementary schools:

... there are for them [the teachers] no cloakroom facilities, no staffroom, no lavatory. Thus, when a master has a free period, he must spend it in a classroom where someone else is teaching, or, if he wants a smoke, betake himself across the school yard to sit in the senior master's car. The Headmaster, denied the luxury of a room of his own, has a desk in the corner of a classroom. It is, accordingly, no unusual occurrence for some thirty boys, a teacher, the Headmaster, a part-time clerk and an anxious parent to be in the room at the same time. To add to the excitement, a telephone intermittently makes itself heard. ${ }^{52}$

Some four years ago I entered a secondary modern school. Built in 1893 ... it was intended to hold 250 boys and even then its playground space must have been appallingly inadequate. Now, with double that number of boys, the playground would be a down-right hazard were it not for the fact that the school had spread itself about the town in halls and private houses (18 boys in a back bedroom) until its total accommodation lay

52 Dent, H. C. Secondary Modern Schools: an Interim Report. London: Routledge and Kegan Paul, 1958: 23. 
within a circle of nine miles circumference. For many classes it was a case of morning assembly followed by morning departure. ${ }^{53}$

Even in new-build SMSs, similar problems were encountered:

Our school is designed for 600 pupils; we have approximately 815 . This necessarily leads to overcrowded rooms and the use of the Crush Hall for 'impossible' lessons ... the frustration of trying to teach well, and failing, shows itself and produces a surprising ... turn-over of staff. The school opened two and a half years ago. Of the original staff of approximately 25 , only five remain. ${ }^{54}$

Rather than addressing material inequalities between established grammar schools and the newer SMSs, the system of funding reinforced them. In 1958, it was estimated that the average grammar school pupil received 170 per cent more per annum, in terms of resources, than the average SMS child. ${ }^{55}$ The situation led Dent to conclude that: 'Too great emphasis can hardly be laid upon the handicap that obsolete and ill-equipped buildings has been and still is' ${ }^{56}$

It soon became clear to discerning observers that these material inequalities were only the most glaring and that more subtle, but pervasive, forms of

\footnotetext{
53 Correspondent. "New Growth in an Old School: Challenge and Response." Times Educational Supplement, $26^{\text {th }}$ August 1960: 239.

54 Correspondent. "Old Habits in a New Town: First Impressions of Secondary Modern Life." Times Educational Supplement, 29 $9^{\text {th }}$ January 1960: 160.

${ }^{55}$ Montgomery, Examinations: an Account, 254.

${ }^{56}$ Dent, Secondary Modern Schools, 142.
} 
inequality were also operating. Then, as now, there was a strong correlation between academic attainment and social class. Thus, although the 1944 Education Act was 'intended to ensure equality of opportunity, [it] had in fact made no more than a marginal change in the situation' ${ }^{57}$ The 'divided secondary system discriminated against children of working class origin and, conversely, favoured the middle class child'. ${ }^{58}$ Thus, although a minority of academically able, working class children did receive a grammar school education, the seemingly meritocratic eleven-plus examination did more to reinforce entrenched social divisions than it did to eliminate them.

Another factor determining the fate of SMSs was the reform of the examining system by the Secondary School Examinations Council (SSEC). ${ }^{59}$ These reforms were, in fact, preceded by an earlier set of proposals published in 1943. The Norwood Report contained radical proposals designed to sweep away external examinations and replace them with a system of certification based on internal examinations and school records for all schools. ${ }^{60}$ It acknowledged that such revolutionary change could not be accomplished overnight, proposing that interim arrangements should be adopted for seven years while schools prepared themselves for new responsibilities. During this time, the School Certificate should cease to be an examination with a group and minimum number of subjects requirements thereby allowing pupils to enter for any

\footnotetext{
${ }^{57}$ Simon, Education and the Social Order, 291.

${ }^{58}$ Ibid., 290.

59 Ministry of Education. Examinations in Secondary Schools: Report of the Secondary School Examinations Council. London: HMSO, 1947.

${ }^{60}$ Board of Education, Curriculum and Examinations.
} 
number and combination of subjects that they wished. Teachers were to become actively involved in its management to gain the experience they would need when school-leaving examinations became their responsibility.

A range of powerful interest groups and opinion leaders was soon mobilised against the revolutionary changes proposed by the Norwood Report. Amongst the first was the Headmasters' Association which voted against Norwood's internal examination proposals in 1944. The examining boards, and individual officers such as Brereton, also made representations to the Ministry which were extremely critical of the proposals. ${ }^{61}$ As a member of the Beloe Committee later observed, the report initiated a 'prolonged controversy'. ${ }^{62}$ The hiatus ended when the SSEC was asked to review the situation. Its report repudiated Norwood's ultimate goal that all examining at sixteen should be conducted internally declaring that 'An external examination is profitable and proper'63 for certain pupils. The SSEC's reforms ensured that defining features of the School Certificate were preserved in the new examination which replaced it. The authorities that had operated the School Certificate were entrusted with developing GCE, a decision which perhaps more than any other ensured the preservation of the status quo. Moreover, the pass level was fixed by adopting the highly coveted credit level from the School Certificate. Although the SSEC accepted Norwood's proposal for making O-Level available on an individual

\footnotetext{
${ }^{61}$ See, for example, Brereton, J. L. The Case for Examinations: an Account of their Place in Education with Some Proposals for their Reform. Cambridge: Cambridge University Press, 1944.

62 "Secondary School Examinations Other than the GCE - the Beloe Report." Journal of the Association of Assistant Mistresses 12, no. 1 (Spring 1961): 58.

${ }^{63}$ Ministry of Education, Examinations in Secondary Schools, 5.
} 
subject basis, beyond that it conceded that its reform ambitions were limited: 'One effect, therefore, of our proposals is to make available what is virtually "School Certificate" on a subject basis'. ${ }^{64}$ It did not, however, reject Norwood's principal proposal out of hand - rather it regarded SMSs as the main site for experiments with school-based examinations and records of achievement.

Sociologists have noted that, as well as selecting the competent, an important role of examinations is maintenance of the existing social order. ${ }^{65}$ The events described above illustrate this phenomenon. Indeed, as Lawn observes, 'detached from the examination system', the SMS, 'like other kinds of low status work [was] able to labour in an unsupervised manner'. ${ }^{66}$ Although the reformed system may be regarded as a compromise between the vested interests of the traditionalists and the radical goals of the progressives, it was a 'clumsy'67 compromise which did not 'satisfactorily me[e]t the realities of the situation' ${ }^{68}$ Coupling a tripartite system of education with unequal examining opportunities reinforced traditional divisions. In reality, then, the odds were stacked against SMSs from the outset. If the much vaunted 'parity of esteem' with grammar schools was ever going to be achieved, it must be accomplished on the back of a multiplicity of inequalities.

\footnotetext{
${ }^{64}$ Ibid., 7.

${ }^{65}$ For instance, see Bourdieu, P. and Passeron, J. C. Reproduction in Education, Society and Culture. London: Sage, 1976. Musgrave's case study of an examination board in Victoria, Australia in Musgrave, P. W. Whose Knowledge? A Case Study of the Victorian Universities Schools Examinations Board. London: Falmer, 1988 also shows how different interest groups jostle, deploying power in pursuit of their own ends.

${ }^{66}$ Lawn, M. Modern Times? Work, Professionalism and Citizenship in Teaching. London: Falmer, 1996: 86.

67 Judges, "Evolution of Examinations", 31.

${ }^{68}$ Ministry of Education, Examinations Other than the GCE, 9.
} 
The following section considers the role of external examinations in determining the fate of SMSs. It explores various functions performed by examinations, showing that whilst some worked against the interests of SMSs, individual schools were able to turn others to their advantage, redressing the balance in their own favour. It is argued that external examinations, promoted by individual teachers acting as change agents, played a key role in those SMSs which managed to overcome the barriers to acceptance that they faced.

\section{The Struggle for Parity of Esteem:}

\section{Contracting in to the 'competition-examination-success' System}

... they are the schools which have been subjected to more calumny and vilification than any other type of school ever evolved in these islands. The use of the term Secondary to denote 'second stage' in 1944 misled many of the general public into the illusion that somehow 'Secondary Education for All' meant 'Grammar School Education for All' ... This was not so, and because of the disillusionment which followed the secondary modern schools bore the brunt of the attack which came from all quarters. $^{69}$

Previously, external examinations had played a decisive role during periods of expansion in secondary education, endowing schools with a sense of purpose and providing public credibility by measuring their work against external

69 Heaton, P. R. "External Examinations in the Secondary Modern School." In External Examinations in Secondary Schools: their Place and Function, edited by G. B. Jeffery. London: Harrap, 1958: 93-94. 
standards. ${ }^{70}$ In the 1940s, secondary education entered a period of unprecedented growth and this need was arguably greater than ever before. If the government had determined that this role should not be played by external examinations, then its own role in nurturing secondary modern education and the development of internal examinations was even more important. However, the Ministry adopted a laissez-faire approach, leaving these initiatives "'deliberately unplanned"'. ${ }^{71}$ As an editorial in the Times Educational Supplement declared, 'The Minister expresses the national policy and looks the other way'. ${ }^{72}$ Likewise, a member of the Beloe Committee observed: 'At the point at which we began our work, the area [examinations for modern schools] ... remained completely uncharted in official policy'. ${ }^{73}$ Instead, official publications clung to the belief that freedom from external constraints would release an internal dynamic which would axiomatically impel SMSs onto rightful courses of action, facilitating the development of a distinct character and traditions. In retrospect, a dereliction of duty seems to lurk just beneath the surface in this championing of freedom.

Without a clear steer from the centre, an atmosphere of uncertainty prevailed and freedom was prone to degenerate into aimlessness:

\footnotetext{
${ }^{70}$ This service is acknowledged by successive official publications including Board of Education, Examinations in Secondary Schools; Board of Education, Curriculum and Examinations; and Ministry of Education, Examinations Other than the GCE.

${ }^{71}$ Harold Loukes quoted in Lawn, Modern Times?, 78.

72 Editorial Comment. Times Educational Supplement, $4^{\text {th }}$ November 1960: 611.

73 "Secondary School Examinations." Journal of the Association of Assistant Mistresses, 61.
} 
"Their future is their own to make". Yes, indeed ... but what sort of future? For many teachers there were no landmarks in this new territory. There were no precise aims or objectives laid down for Secondary Modern education ... no established "yardsticks" by which to measure the value of anything they might attempt. No wonder they felt lost. ${ }^{74}$

The following quotation conveys a yearning for a sense of mission and direction. In it, Waldron deplores the fact that many SMSs:

... follow a timetable which differs in no way from that of the lower forms of a grammar school with the exception of slightly more time for practical subjects. We continually deplore our pupils' lack of interest and inattention and yet in the staffroom it is difficult to find anyone who really believes that radical changes in our methods are possible ... why cannot the secondary modern school which is not bound by any examination syllabus be progressive? Are any secondary modern schools running successfully on a modified project method and if so could we hear about them ${ }^{75}$

In a similar vein, a claim that secondary modern pupils 'wander willy-nilly in a haze of educational haphazard' ${ }^{76}$ prompted the following rebuke: 'May I suggest

\footnotetext{
74 Dent, Secondary Modern Schools, 146-47.

75 Waldron, W. J. in Letters to the Editor. Times Educational Supplement, $5^{\text {th }}$ February $1960:$ 220.

76 Murray, A. in Letters to the Editor. Times Educational Supplement, $8^{\text {th }}$ July 1960: 59.
} 
that is we, the teachers, who wander thus ... somehow we must bring ourselves to face the awful truth; perhaps then we may begin to go forward to the discovery of "how to educate the 80 per cent"'. 77

In the event, freedom was the stumbling block on which many schools foundered. In the absence of clear criteria by which to evaluate the experiments they were encouraged to undertake, schools were vulnerable to the kind of illconceived experimentation which could damage their reputations further still.

... there was, during the early years, a flurry of rather wild and woolly experiment ... It was, unfortunately, only too easy for people not working in Secondary Modern Schools to be critical of those who were ... when experiments ended in chaotic failure ... It would have been more charitable, and more just, to remember both the magnitude and the terrifying vagueness of the task which the teachers in the new secondary schools had to undertake. ${ }^{78}$

Increasingly, schools turned to examinations to fill the void where a sense of purpose should have been. Two important services performed by external examinations, therefore, were to charge SMSs with a much-needed sense of mission and to validate their work:

Many teachers in these schools believe that external examinations can provide, as it were, a landmark by which they can take their bearings and

\footnotetext{
77 Kirkpatrick, W. in Letters to the Editor. Times Educational Supplement, 22 July 1960: 120.

78 Dent, Secondary Modern Schools, 147.
} 
measure their standards and progress, in relation both to what is being achieved by other schools of the same type and to what is demanded by the world around them ... This we have been told is a need which, in this exploratory phase of the development of secondary education ... is keenly felt by many teachers. ${ }^{79}$

Selection is a key function performed by external examinations in meritocratic societies, helping to choose candidates for schools, further and higher education and for jobs. As the non-selective element in a selective system of education, SMSs were, by definition, excluded from this function. Selection cast SMSs in the role of passive victims - never in a position to select on their own behalf yet 'once, twice or even thrice "creamed" , 80 first before their pupils arrived and then again at twelve-plus and thirteen-plus. Heaton describes the corrosive effects of selection in his own school, noting the inbuilt sense of failure and alienation experienced by many newly-arrived pupils. He recalls that: 'Almost the first words uttered by the parents of a new boy in 1950 were "I want him to have another chance for the scholarship"'. ${ }^{81}$ For most pupils, the main objective was to leave school as quickly as possible. For the more able, the twelve-plus and thirteen-plus examinations, designed to re-evaluate pupils who had been wrongly placed by the eleven-plus, offered escape routes. Heaton describes their unsettling effects on the lower half of his school:

\footnotetext{
79 Ministry of Education, Examinations Other than the GCE, 23.

80 Higginson, J. H. in the Foreword to Kneebone, I Work in a Secondary Modern School, x.

81 Heaton, "External Examinations", 96.
} 
... nearly every year there is the upset of an external examination. In the first two years the upset is greatest, for it is then that the external examination is designed to get them out of the school, with the obvious inference that any school is better than the secondary modern school in which they have been unfortunate enough to find themselves ... these boys never settle down to real work during their first year. How can they settle down in a place they intend to leave as soon as possible? ... The next obstacle ... is the thirteen-plus examination ... Again, there is the same wretched business ... of having boys crammed for this examination. Again, there is the disappointment for those many who do not pass ... These two examinations ... were stumbling blocks to all of us in secondary modern schools. ${ }^{82}$

Heaton's is not an isolated experience. When the results of eleven-plus examinations were known, local authorities were inundated by parents whose children had not passed the examination, attempting to secure a place in a school which offered better future prospects than the SMS held out. Initially, these schools had few incentives to offer those destined to remain there for the rest of their school careers and most left as soon as they were able. Many children, on reaching the statutory leaving age, failed even to complete their fourth year of schooling, leaving at the end of the term in which they reached fifteen. Classes containing pupils who knew they would be leaving soon, alongside those who had to stay considerably longer, created an air of

\footnotetext{
82 Ibid., 95-98.
} 
restlessness at the top end of schools similar to that created by the twelve-plus and thirteen-plus in the lower part.

Selection was the only contact that modern schools were intended to have with external examinations, their role restricted to educating the unselected. Initially, then, external examinations may be regarded as being used 'against' SMSs, seriously compromising any pretension they might have to parity of esteem with selective schools. Up and down the country, schools started to rebel against their role as passive victims of competitive examinations. Defying government policy, they contracted in to the 'competition-examination-success' system, ${ }^{83}$ focusing on examinations at the other end of school life: school-leaving qualifications. The following account, provided by the headmaster of the Knoll School for Boys, is typical:

Just over two and a half years ago, I came to a secondary modern school of some 300 boys, none of whom stayed on for a fifth year. The only goal which could be offered to the brightest boys was to pass the entrance examination for the technical institute of a neighbouring authority. $^{84}$

The new head and his staff decided to introduce school-leaving examinations at three separate levels to provide an examination objective for children throughout the ability range: a GCE course for the A stream; a five-year Royal

\footnotetext{
${ }^{83}$ Taylor, "Changing Concepts of the Modern School", 63.

84 Dellan, G. J. "Examinations by the Sea: a Success at Hove." Times Educational Supplement, 10 June 1960: 1194.
} 
Society of Arts course for the B stream and a four-year Union of Educational Institutes qualification for the $\mathrm{C}$ stream. Although the staff agreed that the minimum preparation for O-Level should be three years: 'Last summer, the temptation to experiment proved irresistible: we were glad we did so. Six out of eight boys passed in Mathematics, four out of six in English Language and two out of three in Geography ... All except one ... are staying to take further subjects next summer and some have the prospect of leaving school with up to seven subjects at 'O' Level'. ${ }^{85}$ As more and more schools advertised their successes, it became apparent that examinations were not infallible selection instruments and that there were considerable reserves of talent in SMSs children able to pass O-Level in a number of subjects and willing to stay at school for a fifth year in order to do so.

There were several forces at work in post-war society which reinforced the growth of external examining and undermined the SSEC's attempts to make certification an increasingly internal affair. First, there was an ever-widening demand for paper qualifications which was filtering down from professional and white collar occupations to blue collar work: 'It is only since the war that educational certificates have come to be at all widely demanded as minimum qualifications for entry to apprenticeships'. ${ }^{86}$ This combined with the growth of towns and cities, and greater levels of social mobility, to make internal leaving certificates, with limited local currency, impracticable. As a teacher whose school had complied with government policy noted, the problem with internal

\footnotetext{
85 Ibid.

${ }^{86}$ Morris, R. N. "Fifth-Year Courses in Birmingham's Modern Schools." Educational Review 12, no. 1 (November 1959): 35.
} 
certificates was that: 'we know, and the children realise as well, that the piece of paper is really worthless, except perhaps within the small environs of the local town'. ${ }^{87}$ Another important function performed by examinations in meritocratic societies, therefore, is certification. External examination certificates embodied two indispensable features: wider currency and a relationship with external standards. However, the benefits to be derived from school-leaving examinations extended far beyond the provision of certificates for successful candidates.

Educational sociologists such as Banks observed that the status of schools derives largely from the social level of the career openings they can offer their pupils and that this, in turn, depends upon the examinations for which the schools are able to prepare them. ${ }^{88}$ Images highlighting the role of examinations as 'gate-keepers', opening or closing doors to future life chances, are common in the literature of the period. For instance, Blishen noted that government policy had created a 'feeling of having been shut out' ${ }^{89}$ amongst SMSs whereas success in examinations was a 'coveted Open Sesame'. 90 Heaton agreed, claiming: 'the children feel that the door is open to them' ${ }^{91}$ Another headteacher argued that examinations had replaced the view of his school as a "dead-end" for "also-rans" with the knowledge that it is indeed a place of opportunity', claiming that 'full stature at 16 has in no way been limited

\footnotetext{
87 Murray, in Letters to the Editor, 59.

88 Banks, O. Parity and Prestige in English Secondary Education: A Study in Educational Sociology. London: Routledge and Kegan Paul, 1955.

${ }^{89}$ Blishen, E. "The Future of the Secondary Modern School." Forum 4, no. 2 (Spring 1962): 47.

${ }^{90}$ Dent, Secondary Modern Schools, 158.

${ }^{91}$ Heaton, "External Examinations", 101.
} 
by the outlook at 11 plus'. ${ }^{92}$ The equation of 'full stature at 16' with access to examinations suggests how closely the quest for parity of esteem was bound up with success in examinations, especially O-Level.

The introduction of examinations was found to have a 'tonic' effect which suffused the life of schools, extending beyond the small group of pupils who sat GCEs. The Headmaster of the Knoll School described the volte-face his school experienced in just two and a half years: '... over 80 per cent [of parents] give a written undertaking that their sons shall remain for five years. Whereas previously there was no school uniform, it is now worn by 95 per cent of the boys ... The 300 [pupils] referred to at the beginning is now 460'.93 Other heads reported similar experiences:

My experience is not unique, as I know from many talks with colleagues ... whereas a few years ago every boy in the first year wished to take the over-age twelve-plus test, the candidates now are less than 4 per cent of the intake ... The average boy in the fourth year, no matter what his academic quality, now stays on for the full four years ... The fifth year will include 20 to 30 per cent of their year group. ${ }^{94}$

\footnotetext{
92 Crofts, F. A. "Developing Advanced Courses in the Modern Secondary Schools." Forum 1, no. 1 (Autumn 1958): 22.

93 Dellan, "Examinations by the Sea", 1194.

${ }^{94}$ Heaton, "External Examinations", 101-102.
} 
Turning these schools into places of examination opportunity had made them places of choice for many more pupils. As schools gained in public credibility, morale rose too as is illustrated by the following account of an overheard conversation between three children:

... each insisted that their school was recognised as the best in Birmingham. They were obviously proud of their schools. But ... the discussion almost petered out when they all revealed possession of the trump card, 'Our school has a GCE stream!' This experience suggests that among secondary modern children where GCE work is done, it may become the criterion of a good school. ${ }^{95}$

It also illustrates how the fillip conferred by prestigious examinations could have a 'ripple effect', pervading an entire school which contracted into the 'competition-examination-success' ${ }^{96}$ system. This effect was noted as early as $1868 .^{97}$

As this ripple effect widened, there were other, less tangible, but no less potent, benefits. Some teachers reported a change in school climate:

... there is new air breathing through the secondary schools today. It is an air of purpose resulting from the presence of older pupils who have

\footnotetext{
95 Rapstoff, C. "Bi-Polarity in the Secondary Modern School." Forum 2, no. 3 (Summer 1960): 98. 
shown, by staying, that the school has something it is worth their while to get ... It shows in improved standards of work. It is apparent in the quality of both the teaching and the learning. It shows in many ways in the corporate life of the school. ${ }^{98}$

The extra-curricular life of schools was also invigorated: 'It lifts up the whole of the standards throughout the school ... many sides of the school can flourish, and the crafts, drama and debate take on a greater liveliness'. ${ }^{99}$

Similar findings emanated from systematic studies conducted during this period. For instance, Bournemouth Education Committee's report on the introduction of O-Level in each modern school in its borough noted:

There is now a sense of purpose in the secondary modern schools, and the older pupils have introduced a dignity and maturity which has a highly beneficial impact throughout the school ... At the end of the period over 40 per cent of the pupils stay on at school for a full five-year course ... which is the best testimony that parents can give to the scheme. There has been a noticeable lessening of tension about the outcome of the common entrance examination, and visits to the office by parents of children who have not qualified for a place in the grammar schools have shrunk to negligible proportions. ${ }^{100}$

\footnotetext{
98 Crofts, "Developing Advanced Courses", 24.

99 Heaton, "External Examinations", 104 and 109.

100 Smedley, W. R. "GCE in the Secondary Modern School: a Progress Report on Bournemouth." Education 15 (May 1959): 1037. Other examples of systematic research
} 
Success in examinations was not only part of schools' struggle for enhanced esteem - it was also a way for teachers to demonstrate their worth. Taylor noted that SMS teachers were 'in an inferior position' on five of the six factors in an index used to judge teachers' status. ${ }^{101}$ They were, according to Blishen, engaged in a constant struggle against a 'sense of inferior professional quality' which 'eats away' at them 'continually'. ${ }^{102}$ Contracting into the 'competitionexamination-success' system provided an effective means of boosting professional status. For instance, Adsum describes how a two-tier system developed in his school, with teachers of GCE subjects being paid special allowances and attending separate staff meetings. ${ }^{103}$ Again, a ripple effect ensured that: 'Even though only a minority of teachers ... are concerned with its higher work, the school gains status because of its successes, and the other teachers share in this both personally and collectively'. ${ }^{104}$ In a ruthless admission of this drive to enhance status, one headteacher confessed: 'The GCE pupils will ... raise the tone: the rest can get on as best they can'. ${ }^{105}$

School-leaving examinations were, arguably, the single most important change factor in modern schools' pursuit of parity of esteem. As the Leader in the Times

reporting similar findings include Kirkpatrick, R. V. "An Enquiry into the Effects of Leaving Certificate Examinations upon Pupils' Attitudes." Educational Review 17, no. 2 (February 1965) and Morris, "Fifth-Year Courses", 35.

101 Taylor, Secondary Modern School, 149.

102 Blishen, "The Future", 43.

103 Adsum in Letters to the Editor. Times Educational Supplement, $22^{\text {nd }}$ April 1960: 810.

104 Taylor, Secondary Modern School, 150.

${ }^{105}$ Cui Bono? in Times Educational Supplement, $12^{\text {th }}$ February 1960: 279. 
Educational Supplement argued: 'the very best ... can genuinely claim parity of esteem. But where that has happened ... it is almost invariably because a school has prepared its ablest pupils for the G.C.E. ... the way to public esteem is through success in nationally recognised examinations'. ${ }^{106}$ This is not to deny that the problems facing these schools were many and complex, nor to suggest that they were capable of a simple solution. Nevertheless, the evidence points to the omission of external examinations as the key ingredient missing from the secondary modern 'package'. As more and more schools broadcast their successes, and testified to the transmogrifying powers of external examinations, the pressure on others to experiment became ever more compelling. As Morris observed, the movement towards external examining became 'selfpropagating $^{\prime 107}$ and it is this which explains the explosive growth in entry rates described in the second section of this paper. It is this feature which seized the attention of the Beloe Committee, appointed in 1958, to review the vexed question of school-leaving examinations.

In charting the schools' struggle for parity of esteem, this paper has focused on the benefits conferred by examinations. Therefore, the Beloe Committee's reaction to what it found may come as a surprise. The Committee was, in fact, deeply troubled by the trends it detected in current developments, recommending that they should be curbed forthwith. The quotation from Norwood which opens this paper warned against blind confidence in external examinations arguing that the helpful servant may reveal itself, at any moment,

\footnotetext{
106 Leader, Times Educational Supplement, $12^{\text {th }}$ September 1958: 407.

107 Morris, "Fifth-Year Courses", 41.
} 
as a hard and unsympathetic master. It is this darker side of the unchecked growth of external examining which preoccupied the Beloe Committee:

It is clearly of first importance ... to see not only what the pattern is now but what it may be in 1965 or $1970 \ldots$ by the end of the decade, if not before, the business of external examining below the GCE level will have become largely if not entirely concentrated in the hands of a limited group of examining bodies, free to pursue their own policies without reference to the long-term needs of the schools or of the educational system as a whole, growing rapidly and in danger because of their small number and the vast field open to them of becoming increasingly remote from the schools and the teachers they serve. ${ }^{108}$

There is also evidence of a groundswell of discontent in other contemporary sources. The tendency of examinations to become the be-all and end-all of school life', first noted in $1868,{ }^{109}$ was re-asserting itself according to some commentators. For instance, one teacher complained that his school was:

... geared to what may paradoxically turn out to be an iniquitous introduction - that of GCE for secondary modern children. Timetabling these 25 pupils has the effect of throwing out the whole of the rest of the school, since they require extra periods of specific lessons, and therefore

\footnotetext{
${ }^{108}$ Ministry of Education, Examinations Other than the GCE, 19-20.

109 Schools Inquiry Commission, Report of the Commission, 322.
} 
extra rooms and extra teaching time. The timetable has never been in operation for more than one term. ${ }^{110}$

How many other teachers have experienced these conditions in secondary modern schools taking GCE? I walked round such a school and found all those teachers who received one or more hundreds of pounds in special allowances were regularly taking classes of from fiveten bright pupils while I, taking a non-GCE subject, was taking over-size classes (even up to 80 , in the hall) of more backward pupils. ${ }^{111}$

A young teacher ... complained bitterly at a conference for new teachers that one man at his school spent all day coaching one pupil for GCE subjects, while he himself took 38 ' $C$ ' streamers. Such things we know full well are quite common ... many of us heads must have very guilty consciences over the way we run our fifth ... form courses. ${ }^{112}$

As one teacher concluded: 'We are justifiably proud of our successes, but how far have they turned us away from the fundamentals? Let us beware that in the commendable desire for progress, we do not sacrifice the majority of our secondary modern pupils on the altar of ... the GCE class' ${ }^{113}$

\footnotetext{
110 Correspondent, "Old Habits in a New Town", 160.

111 Adsum, Times Educational Supplement, 810.

112 Headmistress in Letters to the Editor. Times Educational Supplement, $5^{\text {th }}$ August 1960: 178.

${ }^{113}$ Pinkus, I. J. in Letters to the Editor. Times Educational Supplement, 11 March 1960: 490.
} 


\section{Concluding Observations}

1965 marks the end of this story for it is then that a state-controlled qualification, the Certificate of Secondary Education (CSE), was introduced thereby eliminating the 'veritable jungle of examinations' ${ }^{114}$ that had sprung up in the 1950s. SMSs, too, were on the wane as Circular 10/65 accelerated the spread of comprehensive schooling. ${ }^{115}$ Nevertheless, important lessons are contained within this brief but turbulent period in the history of school examining.

The poignant story of SMSs' struggle for parity of esteem is also a story illustrating the power of external examinations. Examinations were astonishing enablers, helping schools to surmount the barriers to acceptance that they faced with remarkable swiftness. Some might argue that the price paid for acceptance was a loss of the radical cultural possibilities envisaged for SMSs in the 1940s. In exchange for acceptance, successful SMSs became pale imitations of grammar schools, capable only of qualified success because differences in the schools' intakes made it impossible for them to compete on equal terms. However, the underlying notion that children of average and below average abilities required a distinctive education which the SMS was best equipped to provide is equally open to question. Providing a satisfactory account of this distinctive education and then translating these ideas into practice proved to be extraordinarily elusive goals. ${ }^{116}$ As late as the 1960 s,

\footnotetext{
114 Holmes, M. "Examinations in the Comprehensive School." Forum 3, no. 2 (1961): 51.

115 Department of Education and Science. The Organisation of Secondary Education. (Circular 10/65) 12 July 1965.

${ }^{116}$ McCulloch, Failing the Ordinary Child?, 112-113.
} 
following the failure of most SMSs to fashion a distinct character and traditions, the Newsom Committee continued to wrestle with fundamental questions about the nature, purpose and form of secondary modern education, thereby further discrediting the theory of three distinct types of mind and the associated secondary modern ideal. As Davis later observed on the continuing uncertainties: 'Someone must determine the curriculum; if the Minister will not and the teacher cannot, then the examiner must'. ${ }^{117}$

From their earliest origins in China, written examinations displayed characteristics which 'we must expect to find ... elsewhere'. ${ }^{118}$ Amongst these is their role in maintaining culture and tradition. With the government's capitulation over the Norwood Report's radical proposals, England lost the only chance it has had to dismantle the system of external examining for pupils below the age of eighteen and replace it with school-based assessment. No other official report on the future of school-leaving qualifications, either before or since that date, has been so bold. Even in the 1960s, at the very moment when the bipartite system of schooling was crumbling, a reactionary approach to examining prevailed. The brief of the Beloe Committee was to consider examinations 'other than the GCE', thereby shielding GCE from reform and preserving it as an elite qualification serving the top twenty per cent of the ability range. The creation of an examining hierarchy in which CSE catered for the forty per cent below those provided for by GCE undermined the status of this

\footnotetext{
117 Davis, "Examinations in Secondary Modern Schools", 60.

118 Judges, Evolution of Examinations, 19.
} 
new examination. ${ }^{119}$ Even CSE Grade 1 - intended to be equivalent to a GCE pass - struggled to attain parity of esteem. Thus, as schooling became increasingly comprehensive, the examining system remained divided and unequal. As well as this new bipartism, new forms of exclusion were introduced by a system which left almost half of the nation's children without a nationally accredited school-leaving qualification. The conviction that it was either desirable or possible for a single school-leaving examination to serve the needs of most of the nation's children was still twenty years away. ${ }^{120}$

Finally, this story illustrates the two faces of examinations, their essential ambivalence. The 'testamania'121 currently gripping England has set off a widespread hostility towards external testing which makes it illuminating to return to a period when an entire group of schools was starved of external examinations to consider the outlook that prevailed then. This exercise casts examinations in an unexpected light, serving as a useful reminder that, when properly harnessed, external assessment is seen as a force for good, performing a number of valuable services in schools. Ultimately, then, the story of external examining in SMSs is double-edged, providing a reminder of the positive role which external assessment can play in school life, when judiciously

\footnotetext{
${ }^{119}$ Gipps, C. and Stobart, G. Assessment: a Teachers' Guide to the Issues. London: Hodder and Stoughton, 1993 (second edition): 9.

${ }^{120}$ The General Certificate of Secondary Education, introduced in 1986, replaced GCE and CSE with a unitary examination and attempted to replace the 'pass/fail' notion of examining with the concept of a 'graded' examination composed of seven grades (A-G) and an 'Ungraded' classification.

121 Iven, H. "Testamania: the Proposed Key Stage 3 Pilot Tests." Education 3-13, no. 3 (1992): 30.
} 
used, as well as reinforcing the messages of more recent research ${ }^{122}$ about the dangers when examinations are over-used or misappropriated.

122 See, for example, James, M. "Measured Lives: the Rise of Assessment as the Engine of Change in English Schools." The Curriculum Journal 11, no. 3 (2000): 343-364. 